\title{
Cellular and Molecular Mechanisms Underlying Perturbed Energy Metabolism and Neuronal Degeneration in Alzheimer's and Parkinson's Diseases
}

\author{
MARK P. MATTSON, ${ }^{a}$ WARD A. PEDERSEN, WENZHEN DUAN, \\ CARSTEN CULMSEE, AND SIMONETTA CAMANDOLA
}

Laboratory of Neurosciences, National Institute on Aging,

Baltimore, Maryland 21224, USA

\begin{abstract}
Synaptic degeneration and death of nerve cells are defining features of Alzheimer's disease (AD) and Parkinson's disease (PD), the two most prevalent age-related neurodegenerative disorders. In AD, neurons in the hippocampus and basal forebrain (brain regions that subserve learning and memory functions) are selectively vulnerable. In PD dopamine-producing neurons in the substantia nigra-striatum (brain regions that control body movements) selectively degenerate. Studies of postmortem brain tissue from AD and PD patients have provided evidence for increased levels of oxidative stress, mitochondrial dysfunction and impaired glucose uptake in vulnerable neuronal populations. Studies of animal and cell culture models of AD and PD suggest that increased levels of oxidative stress (membrane lipid peroxidation, in particular) may disrupt neuronal energy metabolism and ion homeostasis, by impairing the function of membrane ion-motive ATPases and glucose and glutamate transporters. Such oxidative and metabolic compromise may thereby render neurons vulnerable to excitotoxicity and apoptosis. Studies of the pathogenic mechanisms of AD-linked mutations in amyloid precursor protein (APP) and presenilins strongly support central roles for perturbed cellular calcium homeostasis and aberrant proteolytic processing of APP as pivotal events that lead to metabolic compromise in neurons. Specific molecular "players" in the neurodegenerative processes in AD and PD are being identified and include Par- 4 and caspases (bad guys) and neurotrophic factors and stress proteins (good guys). Interestingly, while studies continue to elucidate cellular and molecular events occurring in the brain in AD and PD, recent data suggest that both $\mathrm{AD}$ and $\mathrm{PD}$ can manifest systemic alterations in energy metabolism (e.g., increased insulin resistance and dysregulation of glucose metabolism). Emerging evidence that dietary restriction can forestall the development of $\mathrm{AD}$ and PD is consistent with a major "metabolic" component to these disorders, and provides optimism that these devastating brain disorders of aging may be largely preventable.
\end{abstract}

${ }^{a}$ Address for correspondence: Laboratory of Neurosciences, National Institute on Aging, GRC 4FO1, 5600 Nathan Shock Drive, Baltimore, MD 21224. Phone: 410-558-8463; fax: 410-558-8465.

e-mail: mmattson@grc.nia.nih.gov 


\section{INTRODUCTION}

Other chapters in this volume describe the overwhelming evidence that brain energy metabolism is perturbed in AD and PD. Among those data are the many brain imaging studies documenting reduced radiolabeled glucose uptake into brain cells of living AD patients (see refs. 1 and 2 and chapter by Rapoport in this volume), and studies showing reduced mitochondrial function in affected brain regions and in fibroblasts from AD and PD patients. ${ }^{3,4}$ The purpose of the present chapter is to integrate the available information concerning the cellular and molecular events leading to neuronal degeneration in AD and PD to arrive at a "best-guess" working picture of the pathogenesis of these two disorders. Although many of the same neurodegenerative cascades are likely operative in other neurodegenerative disorders (e.g., Huntington's disease and amyotrophic lateral sclerosis), we have elected to focus on AD and PD because these are the two most prominent neurodegenerative disorders, and because the evidence for metabolic disturbances in these disorders is more extensive than for other neurodegnerative disorders. Any consideration of the pathogenesis of $\mathrm{AD}$ and $\mathrm{PD}$ has to include the fact that, although genetic and environmental factors influence risk for these disorders, increasing age is the major risk factor. As is evident from many studies, increased levels of oxidative stress, mitochondrial dysfunction, and metabolic aberrancies are prominent features of aging in many different organ systems including the brain. ${ }^{3,5}$ Critical questions in the field of neurodegenerative disorders therefore include: (1) how do disease-specific initiators promote oxidative stress and mitochondrial dysfunction? (2) how do genetic factors promote neurodegenerative cascades? (3) does altered peripheral energy metabolism (e.g., increased insulin resistance) initiate and/or predispose to neurodegenerative cascades?

In $\mathrm{AD}$, synapses and neurons in brain regions that subserve learning and memory functions, including the hippocampus, entorhinal cortex, basal forebrain, and neocortical association cortices, degenerate. ${ }^{6}$ The brains of AD victims are characterized by extensive extracellular deposits of amyloid $\beta$-peptide (A $\beta)$ and by degenerating neurons that contain abnormal filaments composed mainly of the microtubule-associate protein tau (which is oxidatively modified and hyperphosphorylated). ${ }^{7,8}$ Aberrant proteolytic processing of APP is implicated in initiation of the neurodegenerative cascade in $\mathrm{AD}$, and may promote neurodegeneration by increasing production of neurotoxic forms of $A \beta$ and/or by decreasing production of neuroprotective forms of secreted APP. ${ }^{7}$ Excellent progress in understanding the pathophysiology of AD has been made as a direct result of the identification of three genes (APP, PS-1, and PS-2) in which mutations cause early-onset autosomal dominant $\mathrm{AD} .{ }^{9,10}$ As described below, the two general consequences of these mutations (as elucidated in studies of transfected cells and transgenic mice harboring the mutations) are aberrant APP processing, with increased neuronal vulnerability to excitotoxic and metabolic insults, and apoptosis.

PD is characterized by motor abnormalities including akinesia, tremor, and rigidity that result largely from progressive degeneration of dopaminergic neurons in the substantia nigra (SN). The axons of the $\mathrm{SN}$ dopaminergic neurons form synapses on target neurons in the striatum. It is believed that in PD, and in animal models of PD (see below), the dopaminergic neurons cease producing dopamine long before the cells degenerate and die, and hence the quite striking beneficial effect of L-dopa ad- 


$\begin{array}{ll}\begin{array}{l}\text { ALZHEIMER'S DISEASE } \\ \text { Presence in Neurofibrillary Tangles } \\ \text { 4-hydroxynonenal adducts }\end{array} & \begin{array}{l}\text { Presence in Brain Tissue and/or CSF } \\ \text { Lipid peroxidation products } \\ \text { Oxidized proteins }\end{array} \\ \begin{array}{l}\text { Oxidized proteins } \\ \text { Nitrotyrosine }\end{array} & \begin{array}{l}\text { DNA oxidation products } \\ \text { DNA oxidation products }\end{array} \\ & \\ \text { PARKINSON'S DISEASE } & \\ \text { Presence in Lewy Bodies } & \text { Presence in Brain Tissue } \\ \text { 4-hydroxynonenal adducts } & \text { Free and protein-bound 4-hydroxynonenal } \\ \text { Oxidized proteins } & \text { Oxidized proteins } \\ \text { Nitrotyrosine } & \text { Nitrotyrosine }\end{array}$

FIGURE 1. Evidence for increased oxidative stress in neurons in AD and PD models (see text for discussion and references).

ministration in PD patients during the early stages of the disease. The causes of neuronal degeneration in PD have not been identified, but it is increasingly clear that age-related increases in levels of oxidative stress $^{11,12}$ and mitochondrial dysfunction ${ }^{4}$ play important roles. Two prominent properties of SN dopaminergic neurons that are of potential relevance to their selective vulnerability are their high content of iron and their high levels of the pigment melanin. ${ }^{12}$ Although the specific factors that initiate the neurodegenerative process in PD are unknown, environmental factors appear to be particularly important. ${ }^{13}$ However, a very small percentage of cases of PD are caused by mutations in the $\alpha$-synuclein gene, ${ }^{14}$ and $\alpha$-synuclein is a conspicuous component of Lewy bodies, suggesting a role for abnormalities in the metabolism/function of this protein in PD.

\section{OXIDATIVE STRESS AND PERTURBED MITOCHONDRIAL FUNCTION IN AD AND PD}

Analyses of tissue homogenates from postmortem brain tissue have provided evidence for increased levels of cellular oxidative stress in vulnerable regions of AD and PD brains compared to the same brain regions from age-matched controls and to lessvulnerable brain regions from the same patients. ${ }^{11,12,15-17}$ Immunohistochemical analyses of brain sections from $\mathrm{AD}$ patients reveal increased protein oxidation, protein nitration, and lipid peroxidation in neurofibrillary tangles and neuritic plaques (FIG. 1). ${ }^{15,18,19}$ In addition, levels of the lipid peroxidation product 4-hydroxynonenal in the ventricular CSF of AD patients are increased 2-3-fold compared to age-matched controls. ${ }^{20}$ Consistent with increased levels of cellular oxidative stress in AD are data showing alterations in levels of antioxidant enzymes in vulnerable regions of AD brain. For example, protein and activity levels of catalase were decreased, while levels of $\mathrm{Cu} / \mathrm{Zn}-\mathrm{SOD}$ and $\mathrm{Mn}$-SOD were increased, in vulnerable (and to a lesser extent in nonvulnerable) regions of $\mathrm{AD}$ brain compared to age-matched controls (FIG. 1). ${ }^{21}$ 

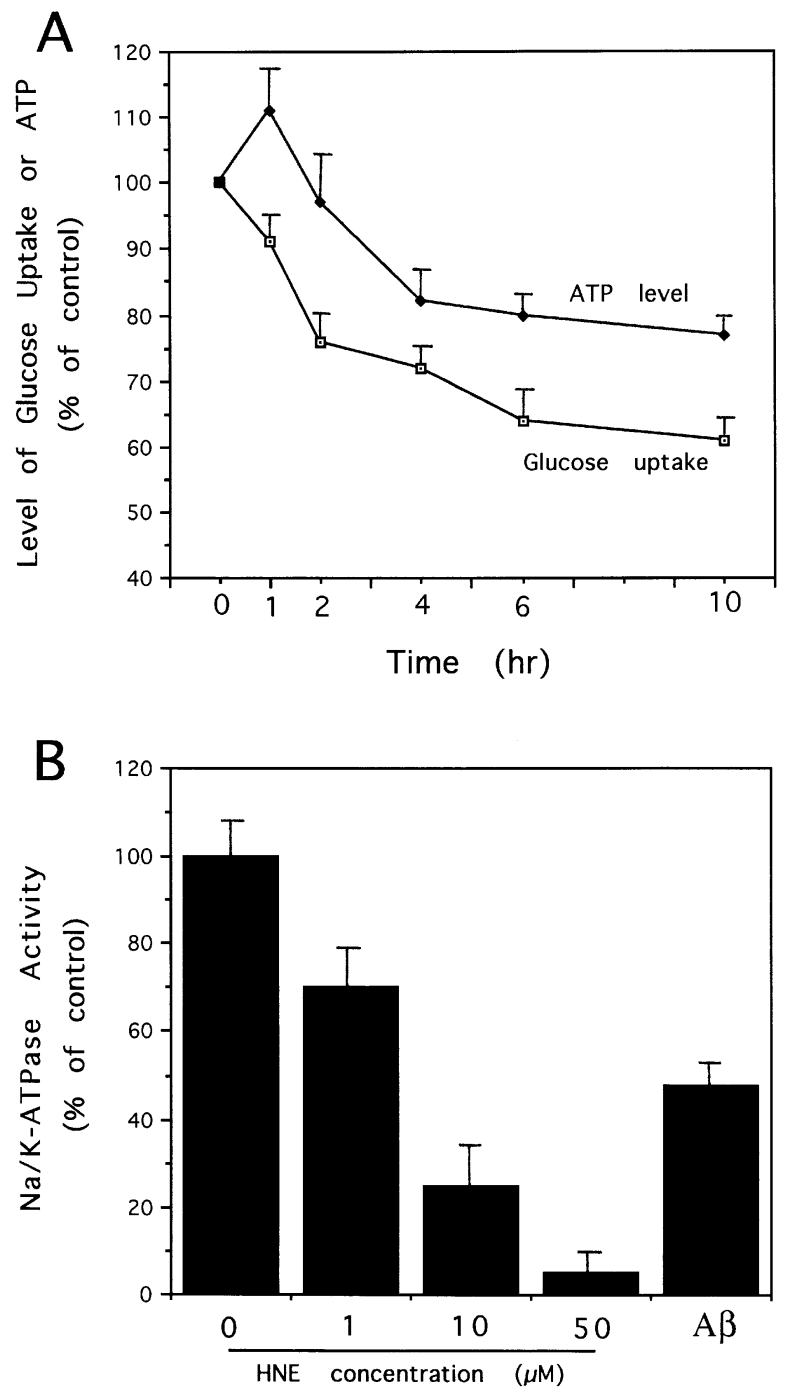

FIGURE 2. AD-relevant insults impair membrane ion-motive ATPase actiivty and glucose transport by a lipid peroxidation-mediated mechanism. A: Cultured rat cortical neurons were exposed to $10 \mu \mathrm{M} \mathrm{A} \beta 25-35$ for the indicated time periods and levels of $\left[{ }^{3} \mathrm{H}\right]$-glucose uptake and cellular ATP levels were quantified (modified from ref. 36). B: Cultured rat hippocampal neurons were exposed to the indicated concentrations of 4-hydroxynonenal (HNE) or $50 \mu \mathrm{M} \mathrm{A} \beta 25-35$ for $3 \mathrm{~h}$ and $\mathrm{Na}^{+} / \mathrm{K}^{+}$-ATPase activity was quantified (modified from Ref. 35).

Analyses of mitochondrial functional parameters in AD brain tissue reveal a striking decrease in activity of $\alpha$-ketoglutarate dehydrogenase complex. ${ }^{22}$ Such mitochondrial abnormalities have also been reported to occur in fibroblasts from AD patients. ${ }^{23}$ 
Data from studies of postmortem brain tissue from PD patients has provided evidence for increased levels of lipid peroxidation ${ }^{11}$ and protein nitration ${ }^{24}$ in substantia nigra of PD patients. In addition, there is an increase in levels of the DNA oxidation product 8 -hydroxyguanine in substantia nigra, ${ }^{25}$ and a generalized increase in protein carbonyls in the brain ${ }^{26}$ in PD patients. Immunohistochemical analyses have shown that levels of the 4-hydroxynonenal are increased specifically in degenerating neurons in SN of PD patients. ${ }^{27}$ A striking feature of PD is a profound decrease in the level of mitochondrial complex I activity in $\mathrm{SN}$, a change that may arise from and/or contribute to increased cellular oxidative stress. ${ }^{4}$ Interestingly, dysfunction can also be observed in mitochondria from peripheral cells from PD patients. Oxidative decarboxylation of pyruvate was impaired in fibroblasts from patients with PD, ${ }^{28}$ and transformation of cells with mitochondria from PD patients resulted in perturbed cellular calcium homeostasis. ${ }^{29}$

\section{ANIMAL AND CELL CULTURE MODELS OF AD AND PD}

What are the events that lead to increased levels of oxidative stress and mitochondrial dysfunction in $\mathrm{AD}$ and $\mathrm{PD}$ ? Increasing age is the major risk factor for both AD and PD, and it can therefore be presumed that the aging process itself plays an important role in promoting oxidative stress in the brain. Because they are postmitotic and have a very high metabolic rate, neurons are particularly susceptible to life-long accumulation of oxidative damage. Age-related alterations in proteolytic processing of APP may play a major role in the increased levels of oxidative stress in neurons in $\mathrm{AD}^{7}$ and, conversely, oxidative stress and metabolic impairment may alter APP processing. ${ }^{30}$ When in an aggregating form (as in the brains of AD patients), A $\beta$ can induce membrane lipid peroxidation in cultured rat hippocampal neurons and human hippocampal synaptosomes. ${ }^{31,32}$ The oxidative stress induced by $\mathrm{A} \beta$ may render neurons vulnerable to excitotoxicity ${ }^{33}$ and apoptosis. ${ }^{34}$ Interestingly, exposure of hippocampal neurons to $\mathrm{A} \beta$ also induces time- and dose-dependent decreases in catalase activity and increases in CuZnSOD and MnSOD activities, ${ }^{21}$ suggesting a role for $\mathrm{A} \beta$ in the altered antioxidant enzyme profile in AD brain. Studies of the impact of lipid peroxidation on cultured hippocampal and cortical neurons suggest a scenario in which lipid peroxidation results in impairment of membrane ion-motive ATPases $\left(\mathrm{Na}^{+} / \mathrm{K}^{+}\right.$-ATPase and $\mathrm{Ca}^{2+}$-ATPase) and glucose transporters (FIG. $\left.2^{32,35,36}\right)$. ATP levels are decreased following exposure of neurons to $A \beta$ or the lipid peroxidation product 4-hydroxynonenal (FIG. $2^{32,36}$ ). This leads to membrane depolarization, energy depletion and disruption of cellular calcium homeostasis. Membrane lipid peroxidation, as induced by $\mathrm{Fe}^{2+}$ or $\mathrm{A} \beta$, also impairs glutamate transport in astrocytes and synaptosomes ${ }^{37,38}$ which would be expected to further promote excitotoxic injury. Consistent with a central role for oxidative stress in the mechanism of $A \beta$-induced neuronal death are data showing that antioxidants (e.g., vitamin E, uric acid, propyl gallate, glutathione and estrogens) protect neurons against $\mathrm{A} \beta$ toxicity. ${ }^{31,35,39,40}$ In addition to its direct actions on neurons, $A \beta$ may also promote metabolic compromise of neurons by damaging vascular endothelial cells. We have found that exposure of vascular endothelial cells to $A \beta$ results in impairment of glucose transport and barrier functions in these cells. ${ }^{41}$ The latter effects of $A \beta$ were prevent- 
TABLE 1. Evidence that metabolic compromise and overactivation of glutamate receptors contributes to the neurodegenerative process in AD and PD

\begin{tabular}{ll}
\hline \multicolumn{1}{c}{ Evidence } & Refs. \\
\hline Glutamate induces neurofibrillary tangle (NFT)-like changes in cultured neurons. & 33,91 \\
Glucose deprivation induces NFT-like changes in cultured neurons. & 92 \\
A $\beta$ induces NFT-like changes in cultured neurons. & 33,93 \\
Excitotoxins induce NFT-like changes in hippocampal neurons of adult rats. & 94 \\
Glucocorticoids and stress enhance NFT-like alterations in vivo. & 94,95 \\
4-hydroxynonenal prevents tau dephosphorylation in cultured neurons & 8 \\
\hline
\end{tabular}

ed by antioxidants, thus implicating oxidative stress in $A \beta$ 's actions on vascular endothelial cells.

Further evidence for the involvement of oxidative stress, metabolic compromise and overactivation of glutamate receptors in the pathogenesis of $\mathrm{AD}$ comes from studies of the neuronal cytoskeleton in cell culture and animal models of AD (see TABLE 1 and references cited therein). Exposure of cultured rat hippocampal neurons to glutamate, $A \beta$ and glucose deprivation results in antigenic changes in tau similar to those present in the neurofibrillary tangles in AD. Calcium influx and increased oxidative stress may be important mediators of such cytoskeletal alterations. Administration of excitotoxins to adult rats elicits antigenic changes in tau similar to those present in neurofibrillary tangles. Interestingly, stress (and consequent glucocorticoid production) exacerbate the AD-like alterations in hippocampal neurons. Neurofibrillary degenerative changes can be suppressed by treatment of neurons with neurotrophic factors and antioxidants (TABLE 1 and M.P.M., unpublished data).

Experimental data demonstrate that AD-relevant insults can impair mitochondrial function in neurons. Exposure of cultured hippocampal neurons and cortical synaptosomes to $\mathrm{A} \beta$ or $\mathrm{Fe}^{2+}$ leads to mitochondrial membrane depolarization and increased levels of mitochondrial ROS. ${ }^{34,37}$ Such mitochondrial dysfunction in these models is secondary to increased oxidative stress because administration of antioxidants or overexpression of Mn-SOD results in preservation of mitochondrial function. ${ }^{37,42}$ The mitochondrial dysfunction, in turn, contributes to the disruption of calcium homeostasis believed to occur in neurons in $\mathrm{AD} .{ }^{43}$ In addition to causing mitochondrial membrane depolarization, and increased mitochondrial oxidative stress and calcium dysregulation, ${ }^{37,42,43} \mathrm{~A} \beta$ can cause damage to mitochondrial DNA $^{44}$ although it is not known if the latter alteration precedes or follows mitochondrial dysfunction.

Analyses of the mechanisms whereby mutations in APP and presenilin-1 (PS-1) cause $\mathrm{AD}$ have proven particularly informative in elucidating the events that result in increased oxidative stress and impaired mitochondrial function in neurons (FIG. 3). APP mutations have been shown to increase production of $A \beta$ in cultured cells and transgenic mice, and the increased amyloidogenesis of $A \beta$ under such conditions is likely to promote oxidative stress and metabolic impairment as described above (and see Ref. 7). In addition to increasing levels of A $\beta$, APP mutations may result in decreased levels of the secreted form of APP (sAPP $\alpha) .{ }^{45,46}$ sAPP $\alpha$ has potent neuroprotective actions on hippocampal neurons in cell culture ${ }^{31,47}$ and in vi- 


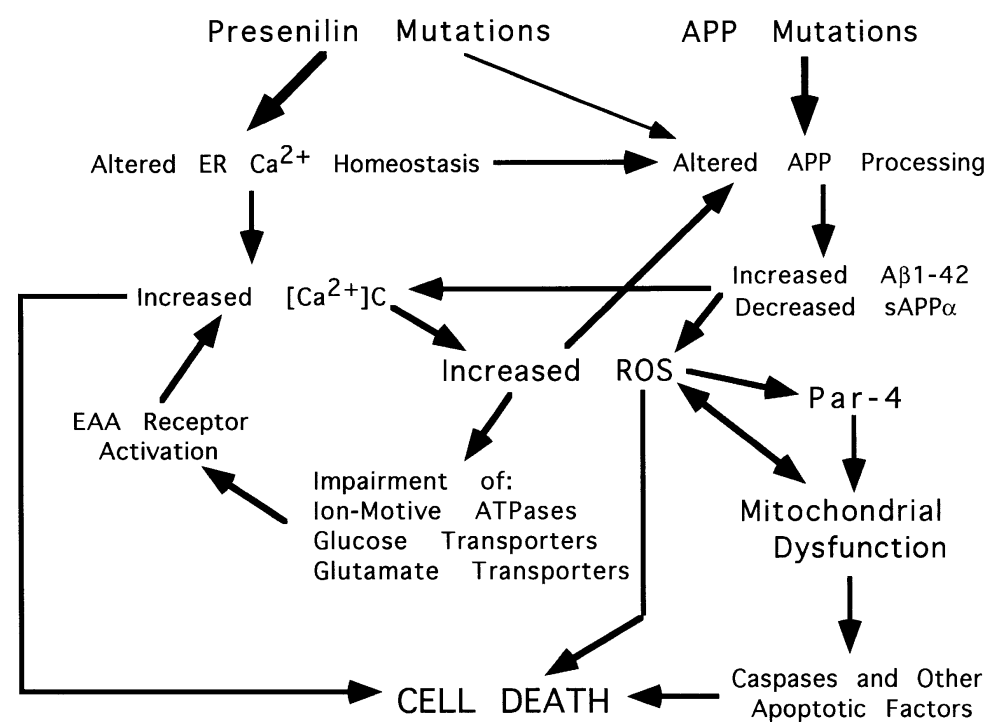

FIGURE 3. Working model for mechanisms whereby mutations in the amyloid precursor protein and presenilin-1 promote neuronal degeneration in AD (see text for discussion).

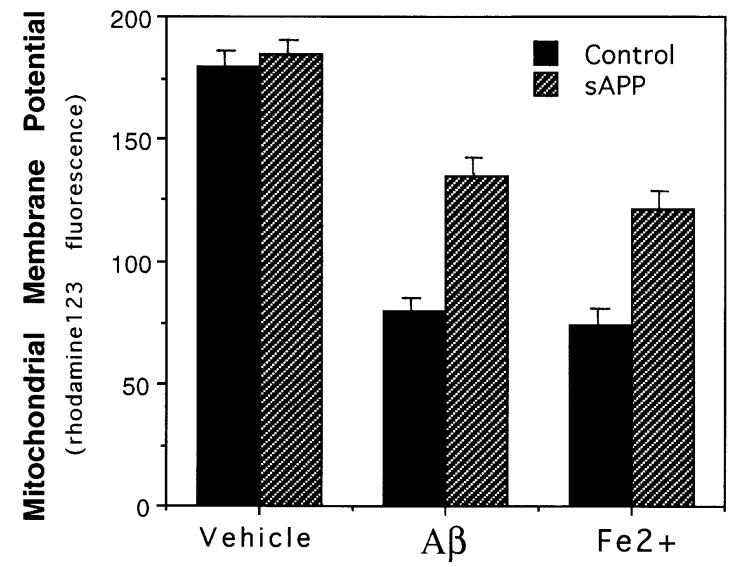

FIGURE 4. Impairment of synaptic mitochondrial function by AD-relevant insults: protective action of $\mathrm{sAPP} \alpha$. Rat cortical synaptosomes were pretreated for $1 \mathrm{~h}$ with $1 \mathrm{nM}$ sAPP $\alpha$ or vehicle (Control). Synaptosomes were then exposed for $4 \mathrm{~h}$ to vehicle, $50 \mu \mathrm{M}$ $\mathrm{A} \beta 25-35$ or $50 \mu \mathrm{M} \mathrm{Fe}^{2+}$ and levels of rhodamine 123 fluorescence (a measure of mitochondrial membrane potential) were quantified. Values are the mean and SEM of determinations made in at least 4 synaptosome preparations.

vo. ${ }^{48}$ Pretreatment of neurons with $\mathrm{sAPP} \alpha$ increases their resistance to oxidative injury induced by $\mathrm{Fe}^{2+}$ and $\mathrm{A} \beta .^{31,45}$ The mechanism whereby sAPP $\alpha$ protects neurons appears to involve activation of potassium channels ${ }^{49}$ and activation of the tran- 
scription factor $\mathrm{NF}-\kappa \mathrm{B},{ }^{50}$ a transcription factor that was recently shown to protect neurons against apoptosis and excitotoxicity in several different culture paradigms. ${ }^{51,52}$ In addition, we recently found that sAPP $\alpha$ induces an increase in the basal level of glucose transport, and attenuates oxidative impairment of glucose transport in cortical synaptosomes. ${ }^{53} \mathrm{sAPP} \alpha$ can also preserve mitochondrial function in synaptosomes exposed to $\mathrm{A} \beta$ or $\mathrm{Fe}^{2+}$ (FIG. 4).

Mutations in presenilins (PS-1 and PS-2) are responsible for many cases of earlyonset autosomal dominant AD. ${ }^{10}$ Presenilins are integral membrane proteins localized predominantly in the endoplasmic reticulum. Expression of AD-linked PS-1 mutations in cultured neural cells and transgenic mice results in aberrant processing of $\mathrm{APP}^{9}$ and to increased vulnerability of neurons to apoptosis and excitotoxicity. ${ }^{54}$ 57 Data suggest that a primary alteration in neurons expressing mutant PS-1 is perturbed endoplasmic reticulum calcium homeostasis resulting in enhanced calcium release when neurons are "challenged" with physiological (e.g., glutamate) or pathophysiological (e.g. exposure to $A \beta$ ) insults. ${ }^{56,58}$ This perturbed calcium homeostasis appears to contribute to increased levels of cellular oxidative stress and mitochondrial dysfunction in neurons subjected to apoptotic insults. As evidence, manipulations that block calcium release from ER (dantrolene and xestospongin), block influx through plasma membrane voltage-dependent channels (nifedipine), or buffer cytoplasmic calcium (overexpression of calbindin D-28k) protect neurons expressing mutant PS-1 against A $\beta$-induced death. ${ }^{54,55}$ Studies of PS- 1 mutant knockin mice show that a PS-1 mutation increases vulnerability of hippocampal neurons to excitotoxicity in vivo and in cell culture; hippocampal neurons expressing mutant PS-1 exhibit enhanced calcium responses to glutamate. ${ }^{56}$ The importance of oxidative stress and mitochondrial dysfunction in the cell death-enhancing actions of PS-

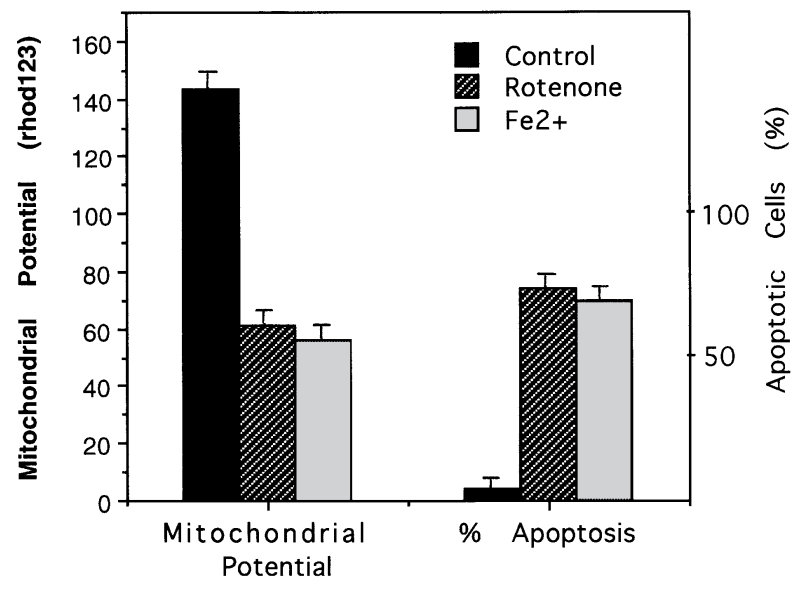

FIGURE 5. The complex I inhibitor rotenone and $\mathrm{Fe}^{2+}$ induce apoptosis of cultured human dopaminergic cells. Cultured SK-N-MC cells were exposed to vehicle (Control), $1 \mu \mathrm{M}$ rotenone or $5 \mu \mathrm{M} \mathrm{Fe} e^{2+}$ and levels of rhodamine 123 fluorescence (a measure of mitochondrial transmembrane potential) and apoptosis were quantified 12 and $24 \mathrm{~h}$ later, respectively. Values are the mean and SEM of determinations made in 4-6 cultures. (Modified from Ref. 61.) 
1 mutations is demonstrated by the ability of the following manipulations to counteract the "endangering" actions of PS-1 mutations: (1) treatment with antioxidants including vitamin E, uric acid and $17 \beta$-estradiol ${ }^{54,59}$; (2) overexpression of manganese superoxide dismutase ${ }^{60}$; (3) treatment of neurons with cyclosporin $\mathrm{A}$, an inhibitor of mitochondrial permeability transition pore formation. ${ }^{42}$

The factors responsible for increased oxidative stress in $\mathrm{SN}$ dopaminergic neurons in PD are not completely clear, but roles for $\mathrm{Fe}^{2+}$, mitochondrial dysfunction, environmental toxins akin to MPTP (1-methyl-4-phenyl-1,2,3,6-tetrahydropyridine), and dopamine itself have been suggested. ${ }^{4,12,13}$ Exposure of cultured dopaminergic cells to $\mathrm{Fe}^{2+}, \mathrm{MPP}^{+}$(the toxic metabolite of MPTP), the complex I inhibitor rotenone, or dopamine can cause cell death ${ }^{61}$ (FIG. 5). An excellent model of PD involves administration of the toxin MPTP to monkeys, which causes a clinical phenotype remarkably similar to that seen in human PD patients. ${ }^{62}$ MPTP administration results in loss of tyrosine hydroxylase production and eventual degeneration of SN dopaminergic neurons. Levels of oxidative stress are increased, and complex I activity is decreased, in SN dopaminergic neurons prior to their degeneration in this model. The role of $\alpha$-synuclein in the neurodegenerative process in PD remains to be established. It is of considerable interest that $\alpha$-synuclein forms aggregates in the cytoplasm of degenerating neurons (Lewy bodies) and that expression of mutant $\alpha$-synuclein in cultured cells may promote their degeneration. ${ }^{63}$ If and how such protein aggregates induce oxidative stress and mitochondrial dysfunction remains to be determined.

Recent studies have identified specific mechanism whereby membrane lipid peroxidation, which appears to be a key event in the neurodegenerative process in both $\mathrm{AD}$ and $\mathrm{PD}$, impairs the function of membrane transport proteins. Lipid peroxidation liberates, from membrane fatty acids, several aldhehydes of varying carbon chain lengths. Among such aldehydes, 4-hydroxynonenal (HNE) appears to play a central role in impairment of protein function. ${ }^{64} \mathrm{HNE}$ covalently modifies proteins on cysteine, lysine and histidine residues. Immunoprecipitation-western blot analyses using antibodies that recognize HNE-modified proteins, in combination with antibodies against specific transport proteins, have demonstrated direct covalent modification of glucose transporter ${ }^{36}$ and glutamate transporter ${ }^{37}$ proteins following exposure of cultured neurons and synaptosomes to insults (e.g., $\mathrm{Fe}^{2+}$ and $\mathrm{A} \beta$ ) that induce membrane lipid peroxidation. Presumably the covalent modification of these transporter proteins by HNE promotes protein crosslinking and impairs protein function.

\section{THE CONCEPT OF "SYNAPTIC APOPTOSIS” AND ITS POSSIBLE ROLES IN AD AND PD}

Synaptic compartments (presynaptic terminals and postsynaptic dendritic spines) are regions of neurons that are exposed to high levels of oxidative and metabolic stress. This is the case largely because glutamate receptors and calcium channels are concentrated in synaptic compartments, and the membrane depolarization and calcium influx resulting from activation of these ion channels results in oxidative stress and a high energy (ATP) demand. There are many sound reasons to believe that syn- 


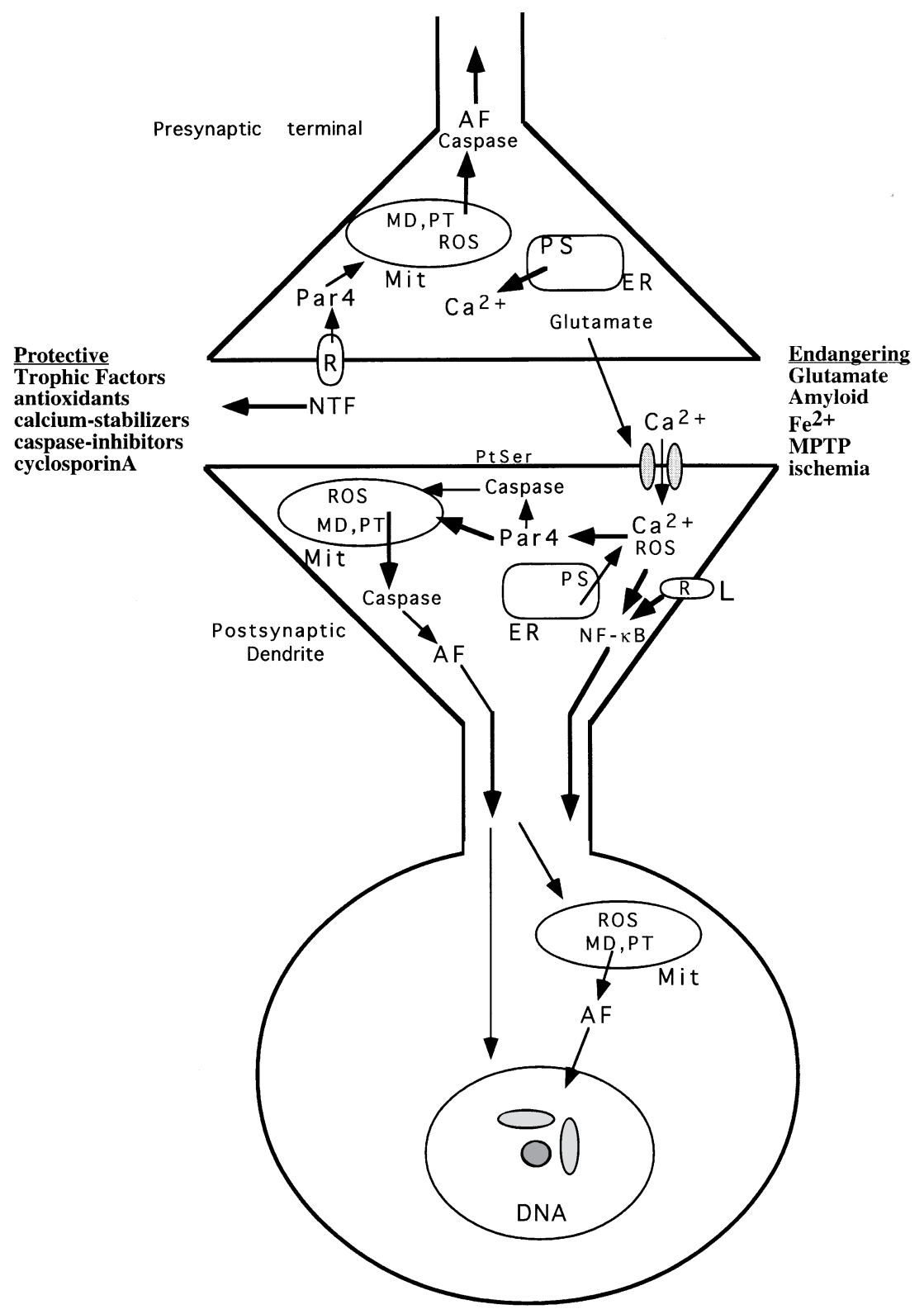

FIGURE 6. Working model of apoptotic biochemical cascades and their roles in synaptic degeneration and neuronal death. See text for discussion. (Modified from Ref. 67.)

apses are the sites where the neurodegenerative process begins in AD and PD (as well as in other neurodegenerative conditions). First, the extent of synapse loss is tightly correlated with cognitive deficits in $\mathrm{AD}$ patients, ${ }^{6}$ and synapse loss in stria- 
A

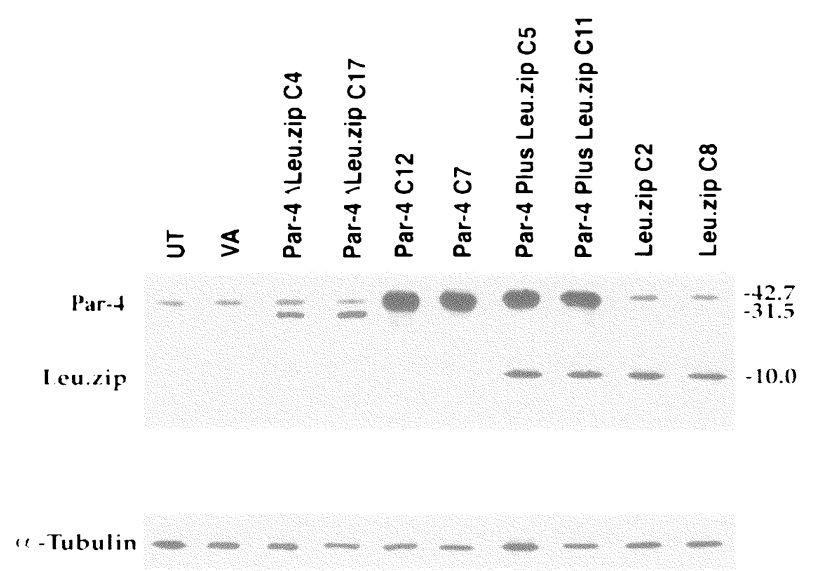

B

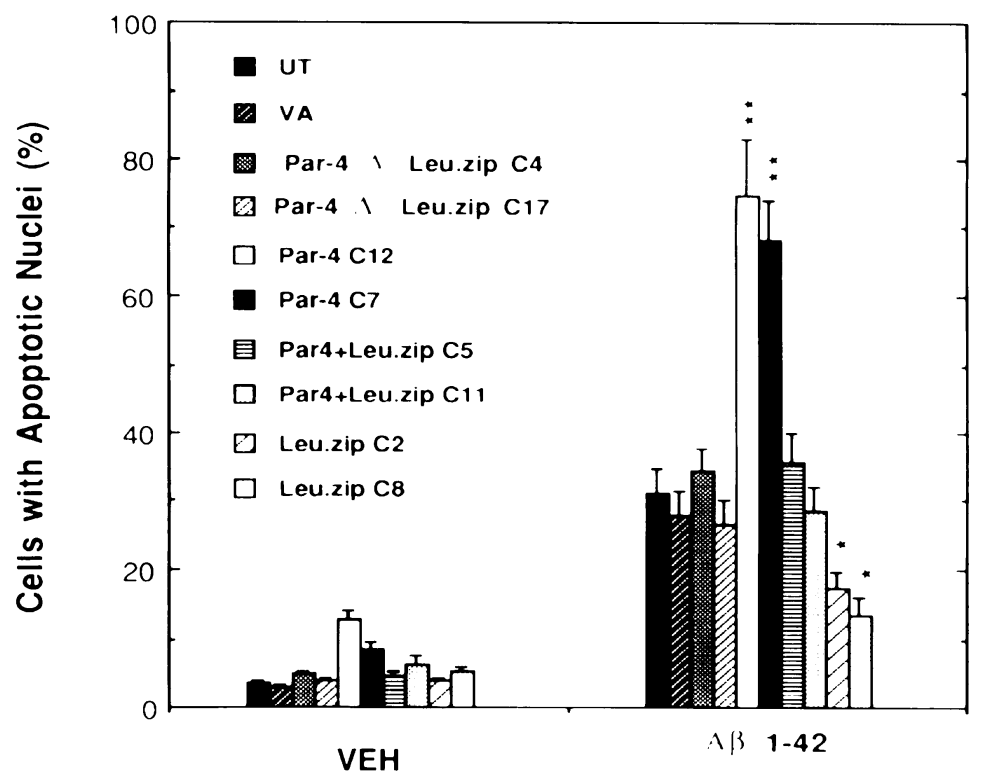

FIGURE 7. Evidence that Par-4 suppresses NF- $\kappa \mathrm{B}$ activation and promotes neuronal apoptosis. A: Western blot analysis of Par-4 protein levels in selected PC12 cell clones: UT, untransfected; VA, clones transfected with vector alone; Par-4 4 Leu.zip, clones expressing Par-4 lacking the leucine zipper domain; Par-4, clones overexpressing full-length Par-4; Leu.zip, clones expressing the leucine zipper domain of Par-4. B: Cultures of the indicated PC1 2 cell clones were exposed for $24 \mathrm{~h}$ to vehicle (VEH) or $50 \mu \mathrm{M} \mathrm{A} \beta 1-42$ and the percentage of cells with apoptotic nuclei quantified (modified from Ref. 71). 


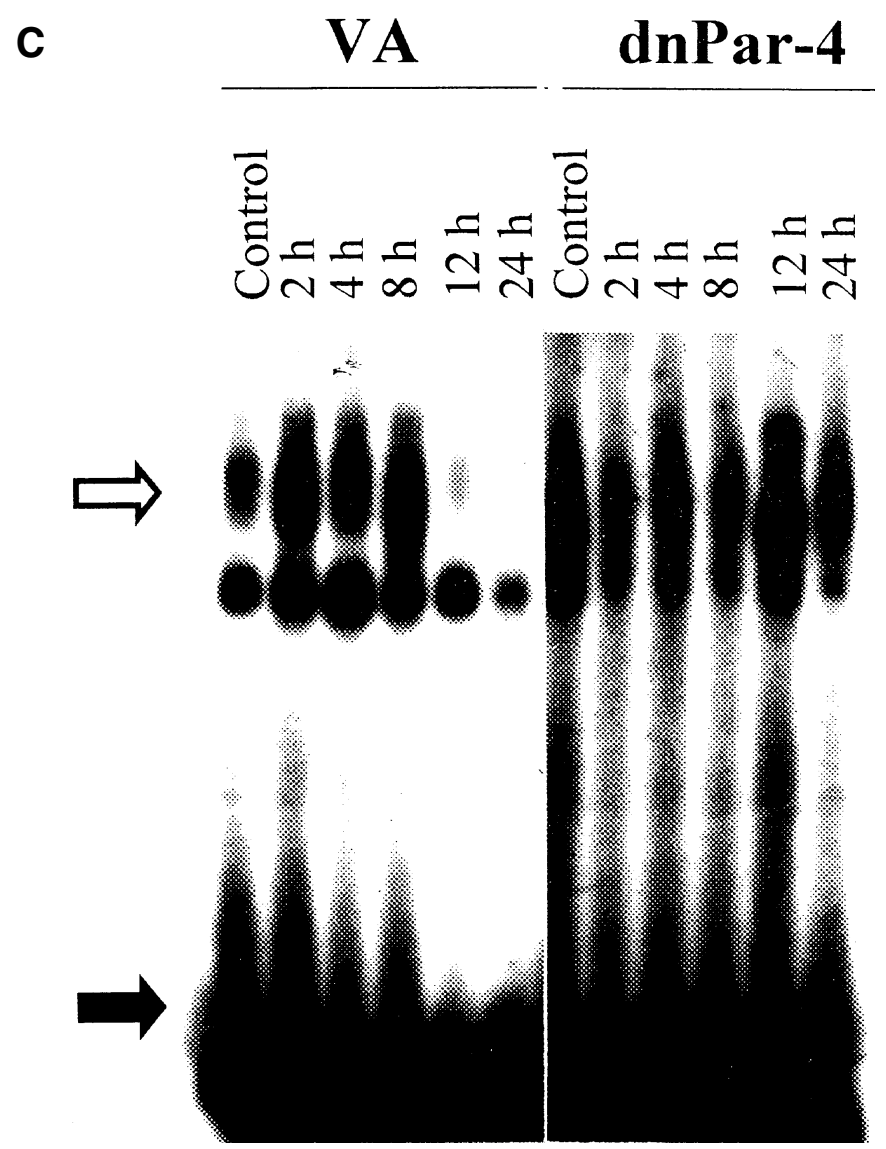

FIGURE 7 (continued). C: Gel-shift analysis of activated NF- $\kappa \mathrm{B}$ prior to (Control) and at the indicated time points following trophic factor withdrawal in vector-transfected PC12 cells (VA) and PC12 cells overexpressing the dominant negative Par-4 leucine zipper domain (dnPar-4). Each lane was loaded with $5 \mu \mathrm{g}$ of cell protein.

tum also appears to correlate with motor dysfunction in PD patients. ${ }^{65}$ Second, overactivation of glutamate receptors, which are localized to postsynaptic regions of neuronal dendrites, plays an important role in the neuronal death process in several different animal and cell culture models of $\mathrm{AD}^{33,35,56}$ and PD. ${ }^{66}$ Third, recent studies have shown that apoptotic biochemical cascades are activated in vulnerable neuronal populations in $\mathrm{AD}$ and $\mathrm{PD}$, and can also be activated locally in synaptic compartments following exposure to insults relevant to $\mathrm{AD}(\mathrm{A} \beta)$ and $\mathrm{PD}\left(\mathrm{MPP}^{+}\right.$and rotenone $)^{67-69}$ (FIG. 6). The latter studies showed that exposure of synaptosomes or intact synaptically connected neurons to disease-relevant insults results in the following apoptosis-related events: caspase activation; loss of plasma membrane phospholipid asymmetry; induction of Par-4 expression (at the translational level); 
mitochondrial membrane depolarization; mitochondrial oxyradical production; mitochondrial calcium uptake; and release into the cytosol of factors capable of inducing nuclear chromatin condensation and fragmentation.

Recent findings from studies of postmortem brain tissue, and animal and cell culture models, suggest that Par-4 (prostate apoptosis response-4) may serve as a critical link in the chain of events that leads neuronal degeneration in AD and PD. Par-4 is a leucine zipper and death domain-containing protein originally identified for its role in apoptosis of prostate cells, ${ }^{70}$ and more recently implicated as a pivotal effector of neuronal apoptosis. ${ }^{71}$ Levels of Par- 4 mRNA and protein are increased in vulnerable regions (and to a lesser extent in nonvulnerable regions) of AD brain. ${ }^{71}$ The latter study also showed that approximately $40 \%$ of neurofibrillary tangle-bearing neurons are also Par-4 immunoreactive, thus establishing a direct relationship between increased Par-4 expression and neuronal degeneration in AD. Cell culture data further suggest a central role for Par-4 in the cell death process in AD. Par-4 levels increase wihin 1-2 hours of exposure cultured hippocampal neurons to $A \beta$, and treatment of the neurons with a Par- 4 antisense oligonucleotide prevents neuronal apoptosis. ${ }^{71}$ Par- 4 induction occurs prior to, and is required for, mitochondrial dysfunction and caspase activation following exposure of neurons to $A \beta$. Overexpression of the Par-4 leucine zipper domain prevents apoptosis (FIG. $7^{71}$ ), suggesting a necessary role for Par-4 interactions with another protein in its pro-apoptotic action. Par-4 interacts with regulatory domain of $\mathrm{PKC} \zeta$ and this interaction may inhibit the enzymatic activity of PKC $\zeta .^{72}$ We have recently found that Par-4 induction suppresses activation of the transcription factor NF- $\mathrm{KB}$ in PC12 cells (FIG. 7), which may promote apoptosis because activation of NF- $\mathrm{KB}$ prevents neuronal death induced by a variety of oxidative and metabolic insults. ${ }^{51,52}$

Par-4 levels increase dramatically in midbrain dopaminergic neurons of monkeys and mice exposed to MPTP. ${ }^{61}$ The increase in Par-4 levels occurs in both neuronal cell bodies in the substantia nigra and their axon terminals in the striatum, and precedes loss of tyrosine hydroxylase immunoreactivity and cell death. Interestingly, Par-4 levels also increase following MPTP administration in neurons in the red nucleus, lateral geniculate nucleus and cerebral cortex. ${ }^{61}$ Par-4 may play a role in neuronal dysfunction and/or apoptosis in the latter brain regions because, previous studies have documented metabolic alterations and/or neurodegenerative changes in these regions. ${ }^{73}$ Exposure of cultured human dopaminergic neural cells to the complex I inhibitor rotenone, or to $\mathrm{Fe}^{2+}$, resulted in $\mathrm{Par}-4$ induction, mitochondrial dysfunction, and subsequent apoptosis. ${ }^{61}$ Blockade of Par- 4 induction by antisense treatment prevented rotenone- and $\mathrm{Fe}^{2+}$-induced mitochondrial dysfunction and apoptosis demonstrating a critical role for Par-4 in the cell death process. Collectively, the data therefore suggest that Par-4 is a mediator of neuronal apoptosis associated with the pathogenesis of PD.

\section{DO PERIPHERAL ALTERATIONS IN ENERGY METABOLISM CONTRIBUTE TO THE PATHOGENESIS OF AD AND PD?}

There have been a large number of reports documenting alterations in glucose metabolism in AD patients. ${ }^{1,2}$ Studies of fibroblasts and platelets from AD and PD 
patients add further weight to the evidence for widespread metabolic alterations in these two disorders. ${ }^{23,28,74}$ In addition, several studies have documented "diabeteslike" alterations in AD patients including increased insulin resistance and abnormal glucose tolerance. ${ }^{75,76}$ Moreover, alterations in the hypothalamic-pituitary-adrenal axis that controls glucocorticoid production have been widely reported. ${ }^{77}$ Despite these findings, there is as yet no definitive evidence that a generalized metabolic disturbance precedes and contributes to the neurodegenerative process. We have recently found that glucose regulation is altered in transgenic mice expressing the APP "Swedish" mutation. Specifically, we have found that the APP mutant mice exhibit an altered response in a glucose tolerance test such that levels of glucose rise to much higher levels than in wild-type control mice (FIG. 8). Basal levels of glucose and insulin were not different in the wild-type and APP mutant transgenic mice. The APP mutant mice are hypersensitive to fasting such that they die within days to weeks when subjected to an alternate day feeding regimen. ${ }^{78}$

Studies of PD patients have also provided evidence for altered peripheral glucose metabolism in this disorder. ${ }^{79}$ The alterations are, in general, similar to those in AD and include abnormal glucose tolerance tests and increased insulin resistance. These findings are particularly interesting because studies in rodents indicate that chronic hyperglycemia can cause dysfunction of dopaminergic transmission. ${ }^{80}$

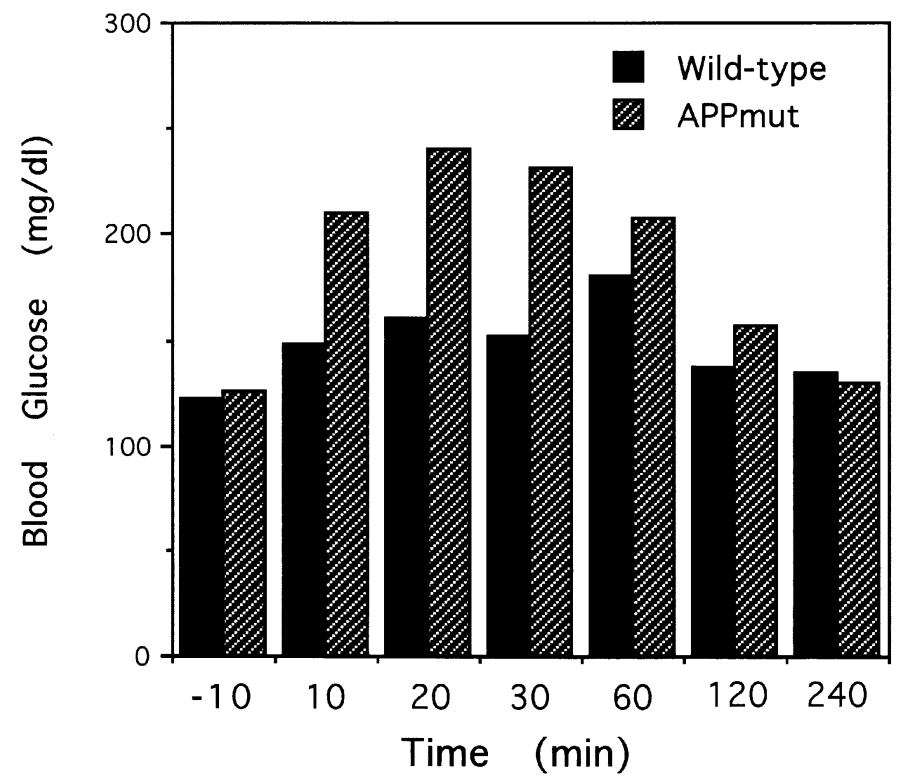

FIGURE 8. Glucose metabolism is altered in transgenic mice expressing an AD-linked APP mutation. Glucose levels were measured in blood samples from wild-type mice and APP mutant transgenic mice (96) taken 10 min prior to and at the indicated time points following administration of an intraperitoneal bolus of glucose. Values are the mean and SD $(n=3-4$ mice $)$. 


\section{CAN DIETARY RESTRICTION PREVENT AD AND PD?}

Despite the convincing evidence that high food intake is a risk factor for age-related disorders such as cardovascular disease and diabetes, the possibility that high food intake might also increase risk for neurodegenerative disorders is largely unexplored. There are several reasons why it might be expected that reduced life-long food intake might ward off age-related neurodegenerative disorders such as AD and PD. First, dietary restriction (DR; reduced calorie intake with maintenance of miconutrient and vitamin nutrition) dramatically extends lifespan and reduces development of age-related disease in rodents ${ }^{81}$ and monkeys. ${ }^{82,83}$ Second, DR reduces levels of cellular oxidative stress in several different organ systems including the brain. ${ }^{81,84,85}$ Third, epidemiological data suggest that the incidences of AD and PD are lower in countries with low per capita food consumption (e.g., China and Japan) compared to countries with high per capita food consumption (e.g., USA and Canada). ${ }^{86}$

We have begun to critically test the hypothesis that DR will increase resistance of neurons to $\mathrm{AD}, \mathrm{PD}$ and other age-related neurodegenerative conditions. In one set of experiments rats were fed ad libitum (AL) or were maintained on an alternate day feeding schedule (DR) for periods of 2 weeks to 4 months. The rats were then administered either kainate (an excitotoxin that selectively damages hippocampal CA3 and CA1 neurons) or 3-nitropropionic acid (3NP, a mitochondrial toxin that selectively damages striatal neurons). Kainate-induced hippocampal damage and associated deficits in visuospatial memory were markedly reduced in rats maintained on DR for 3-4 months compared to AL-fed rats. ${ }^{87} 3 \mathrm{NP}$-induced damage to striatal neurons and associated motor deficits were significantly attenuated in rats maintained on the DR diet. Mice maintained on DR for 3-4 months were relatively resistant to MPTP-induced loss of tyrosine hydroxylase-positve neurons in the SN, and associated behavioral deficits, compared to AL-fed mice (FIG. $9^{88}$ ).

Reasoning that DR exerts its neuroprotective actions by a mechanism involving reduced glucose availability to neurons, we endeavored to mimick the effect of DR in AL-fed rats. To this end we determined whether administration of 2-deoxy-D-glucose (2DG), a non-metabolizable analog of glucose, to adult rats would result in increased resistance of neurons to excitotoxic, metabolic and oxidative insults. Rats administered 2DG (daily dose of $100 \mathrm{mg} / \mathrm{kg}$ body weight for 7 days) exhibited increased resistance of hippocampal neurons to kainate-induced damage ${ }^{89}$ and increased resistance of cortical and striatal neurons to focal ischemia-reperfusion injury. ${ }^{90}$ The vulnerability of SN dopaminergic neurons to MPTP-induced damage was decreased in mice administered 2DG. ${ }^{88}$ In all three animal models behavioral outcome was significantly improved in animals pretreated with 2DG. The beneficial effects of 2DG on brain neurons in vivo are likely due to direct effects of 2DG on the neurons. As evidence, pretreatment of cultured hippocampal neurons with 2DG increases their resistance to excitotoxic, metabolic and oxidative insults. ${ }^{89,90}$ Similarly, 2DG pretreatment protects cultured human dopaminergic cells against death induced by rotenone and $\mathrm{Fe}^{2+} .88$

Collectively, the findings suggest that DR may protect the brain by a mechanism involving a "conditioning" response in which the DR can be viewed as a mild stress that induces upregulation of stress proteins in neurons. If DR exerts similar benefi- 


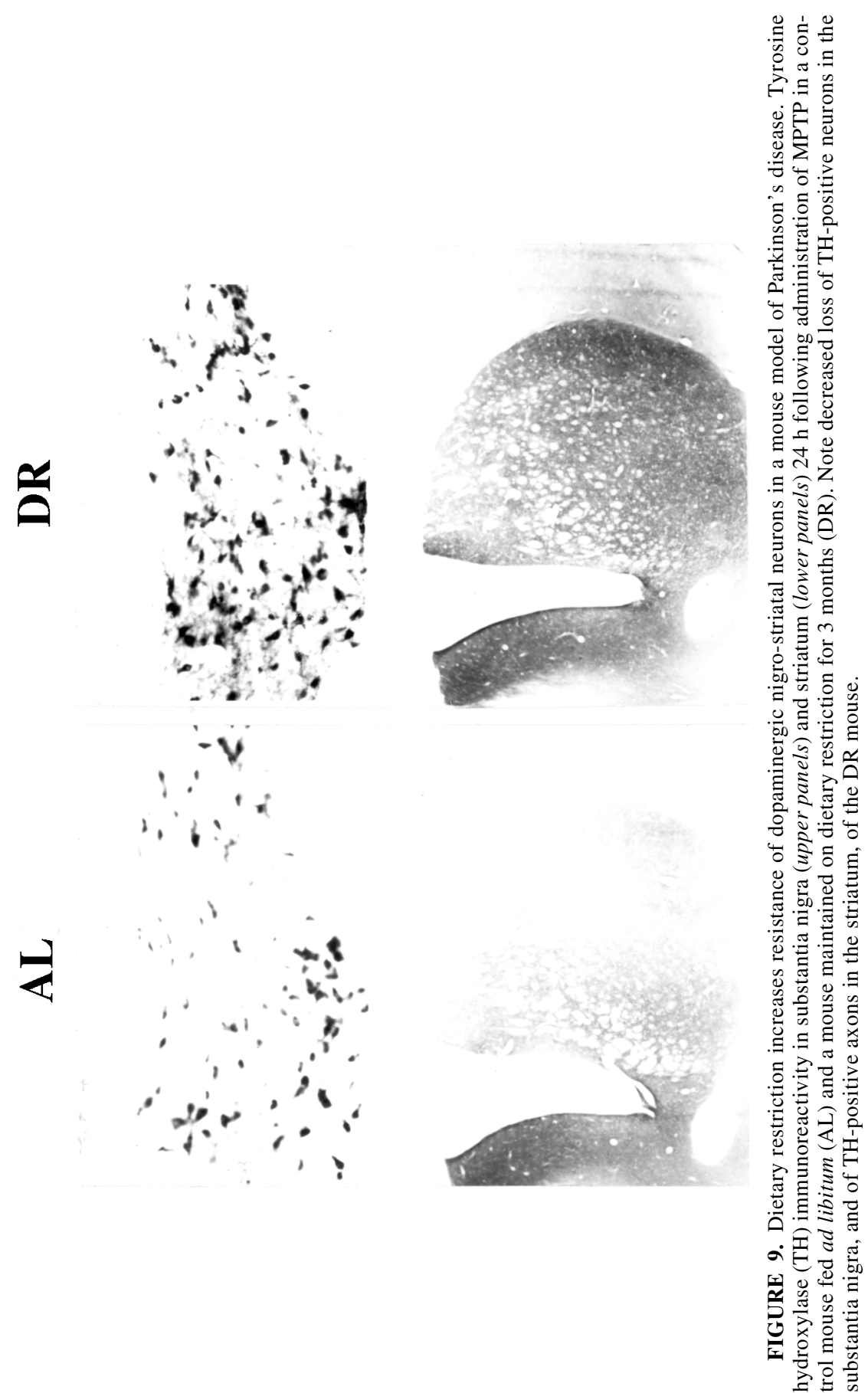


cial effects in humans then DR may be a useful approach for reducing the incidence and severity of several different age-related neurodegenerative conditions.

\section{ACKNOWLEDGMENTS}

Research presented in this paper was supported by grants to M.P.M. from the NIH (NIA and NINDS).

\section{REFERENCES}

1. Hoyer, S., R. Nitsch \& K. Oesterreich. 1991. Predominant abnormality in cerebral glucose utilization in late-onset dementia of the Alzheimer type: a cross-sectional comparison against advanced late-onset and incipient early-onset cases. J. Neural Transm. 3: 1-14.

2. Jagust, W.J., J.P. Seab, R.H. Huesman, P.E. Valk, C.A. Mathis, B.R. Reed, P.G. CoXson \& T.F. Budinger. 1991. Diminished glucose transport in Alzheimer's disease: Dynamic PET studies. J. Cereb. Blood Flow Metab. 11: 323-330.

3. Benzi, G. \& A. Moretti. 1997. Contributions of mitochondrial alterations to brain aging. In The Aging Brain. M.P. Mattson \& J.W. Geddes, Eds. JAI Press. Greenwich, CT. Adv. Cell Aging Gerontol. 2: 129-160.

4. Schapira, A.H., M. Gu, J.W. Taanman, S.J. Tabrizi, T. Seaton, M. Cleeter \& J.M. CoOPER. 1998. Mitochondria in the etiology and pathogenesis of Parkinson's disease. Ann. Neurol. 44: S89-S98.

5. Butterfield, D.A. \& E.R. Stadtman. 1997. Protein oxidation processes in aging brain. In The Aging Brain. M.P. Mattson \& J.W. Geddes, Eds. JAI Press. Greenwich, CT. Adv. Cell Aging Gerontol. 2: 161-191.

6. DeKosky, S.T., S.W. SchefF \& S.D. STYRen. 1996. Structural correlates of cognition in dementia: quantification and assessment of synapse change. Neurodegeneration 5: 417-421.

7. Mattson, M.P. 1997. Cellular actions of $\beta$-amyloid precursor protein, and its soluble and fibrillogenic peptide derivatives. Physiol. Rev. 77: 1081-1132.

8. Mattson, M.P., W. Fu, G. WAEG \& K. UChIDA. 1997. 4-hydroxynonenal, a product of lipid peroxidation, inhibits dephosphorylation of the microtubule-associated protein tau. NeuroReport 8: 2275-2281.

9. Hardy, J. 1997. Amyloid, the presenilins and Alzheimer's disease. Trends Neurosci. 20: $154-159$.

10. Mattson, M. P. \& Q. Guo. 1998. The Presenilins. Neuroscientist 5: 112-124.

11. Dexter, D.T., C.J. Carter, F.R. Wells, F. Javoy-Agid, Y. Agid, A. Lees, P. JenNER \& C.D. MARSDEN. 1989. Basal lipid peroxidation in substantia nigra is increased in Parkinson's disease. J. Neurochem. 52: 381-389.

12. Jenner, P. \& C.W. Olanow. 1998. Understanding cell death in Parkinson's disease. Ann. Neurol. 44: S72-S84.

13. Langston, J.W. 1998. Epidemiology versus genetics in Parkinson's disease: progress in resolving an age-old debate. Ann. Neurol. 44: S45-S52.

14. Polymeropoulos, M.H. 1998. Autosomal dominant Parkinson's disease and $\alpha-$ synuclein. Ann. Neurol. 44: S63-S64.

15. Smith, C.D., J.M. Carney, P.E. Starke-Reed, C.N. Oliver, E.R. Stadtman, R.A. FloYd \& W.R. MARKESBERY. 1991. Excess brain protein oxidation and enzyme dysfunction in normal aging and in Alzheimer disease. Proc. Natl. Acad. Sci. USA 88: $10540-10543$.

16. Moccoci, P., M.S. MacGarvey \& M.F. Beal. 1994. Oxidative damage to mitochondrial DNA is increased in Alzheimer's disease. Ann. Neurol. 36: 747-751. 
17. Lovell, M.A., W.D. Ehmann, S.M. Butler \& W.R. Markesbery. 1995. Elevated thiobarbituric acid-reactive substances and antioxidant enzyme activity in the brain in Alzheimer's disease. Neurology 45: 1594-1601.

18. Smith, M.A., P.L.R. Harris, L.M. SAyre, J.S. Beckman \& G. Perry. 1997. Widespread peroxynitrite-mediated damage in Alzheimer's disease. J. Neurosci. 17: 2653-2657.

19. Good, P.F., P. Werner, A. Hsu, C.W. Olanow \& D.P. Perl. 1996. Evidence of neuronal oxidative damage in Alzheimer's disease. Am. J. Pathol. 149: 21-28.

20. Lovell, M.A., W.D. Ehmann, M.P. Mattson \& W.R. MARKesbery. 1997. Elevated 4-hydroxynonenal levels in ventricular fluid in Alzheimer's disease. Neurobiol. Aging 18: 457-461.

21. Bruce, A.J., S. Bose, W. Fu, C.M. Butt, M.-E. Mirault, N. Taniguchi \& M.P. Mattson. 1997. Amyloid $\beta$-peptide alters the profile of antioxidant enzymes in hippocampal cultures in a manner similar to that observed in Alzheimer's disease. Pathogenesis 1: 15-30.

22. Gibson, G.E., K.F. Sheu \& J.P. Blass. 1998. Abnormalities of mitochondrial enzymes in Alzheimer disease. J. Neural. Transm. 105: 855-870.

23. Sheu, K.F., A.J. Cooper, K. Koike, M. Koike, J.G. Lindsay \& J.P. Blass. 1994. Abnormality of the alpha-ketoglutarate dehydrogenase complex in fibroblasts from familial Alzheimer's disease. Ann. Neurol. 35: 312-318.

24. Good, P.F., A. Hsu, P. Werner, D.P. Perl \& C.W. Olanow. 1998. Protein nitration in Parkinson's disease. J. Neuropathol. Exp. Neurol. 57: 338-342.

25. Alam, Z.I., A. Jenner, S.E. Daniel, A.J. Lees, N. Cairns, C.D. Marsden, P. JenNER \& B. HALLIWELL. 1997. Oxidative DNA damage in the parkinsonian brain: an apparent selective increase in 8-hydroxyguanine in substantia nigra. J. Neurochem. 69: $1196-1203$

26. Alam, Z.I., S.E. Daniel, A.J. Lees, D.C. Marsden, P. Jenner \& B. Halliwell. 1997. A generalised increase in protein carbonyls in the brain in Parkinson's but not incidental Lewy body disease. J. Neurochem. 69: 1326-1329.

27. Yoritaka, A., N. Hattori, K. Uchida, M. Tanaka, E.R. Stadtman \& Y. Mizuno. 1996. Immunohistochemical detection of 4-hydroxynonenal protein adducts in Parkinson disease. Proc. Natl. Acad. Sci. USA 93: 2696-2701.

28. Mytilineou, C., P. Werner, S. Molinari, A. Di Rocco, G. Cohen \& M. D. Yahr. 1994. Impaired oxidative decarboxylation of pyruvate in fibroblasts from patients with Parkinson's disease. J. Neural. Transm. Park. Dis. Dement. Sect. 8: 223-228.

29. Sheehan, J.P., R.H. Swerdlow, W.D. Parker, S.W. Miller, R.E. Davis \& J.B. TUTTLE. 1997. Altered calcium homeostasis in cells transformed by mitochondria from individuals with Parkinson's disease. J. Neurochem. 68: 1221-1233.

30. Gabuzda, D., J. Busciglio, L. Chen, P. Matsudaira \& B. Yankner. 1994. Inhibition of energy metabolism alters the processing of amyloid precursor protein and induces a potentially amyloidogenic derivative. J. Biol. Chem. 269: 13623-13628.

31. Goodman, Y. \& M.P. MatTson. 1994. Secreted forms of $\beta$-amyloid precursor protein protect hippocampal neurons against amyloid $\beta$-peptide-induced oxidative injury. Exp. Neurol. 128: 1-12.

32. Mark, R.J., K. Hensley, D.A. Butterfield \& M.P. Mattson. 1995. Amyloid $\beta$ peptide impairs ion-motive ATPase activities: evidence for a role in loss of neuronal $\mathrm{Ca}^{2+}$ homeostasis and cell death. J. Neurosci. 15: 6239-6249.

33. Mattson, M.P., B. Cheng, D. Davis, K. Bryant, I. Lieberburg \& R.E. Rydel. 1992. $\beta$-amyloid peptides destabilize calcium homeostasis and render human cortical neurons vulnerable to excitotoxicity. J. Neurosci. 12: 376-389.

34. Kruman, I., A.J. Bruce-Keller, D.E. Bredesen, G. Waeg \& M.P. Mattson. 1997. Evidence that 4-hydroxynonenal mediates oxidative stress-induced neuronal apoptosis. J. Neurosci. 17: 5089-5100. 
35. Mark, R.J., M.A. Lovell, W.R. Markesbery, K. Uchida \& M.P. Mattson. 1997. A role for 4-hydroxynonenal, an aldehydic product of lipid peroxidation, in disruption of ion homeostasis and neuronal death induced by amyloid $\beta$-peptide. J. Neurochem. 68: 255-264.

36. Mark, R.J., Z. Pang, J.W. Geddes, K. Uchida \& M.P. Mattson. 1997. Amyloid $\beta$ peptide impairs glucose uptake in hippocampal and cortical neurons: involvement of membrane lipid peroxidation. J. Neurosci. 17: 1046-1054.

37. Keller, J.N., Z. Pang, J.W. Geddes, J.G. Begley, A. Germeyer, G. Waeg \& M.P. MATTSON. 1997. Impairment of glucose and glutamate transport and induction of mitochondrial oxidative stress and dysfunction in synaptosomes by amyloid- $\beta$ peptide: Role of the lipid peroxidation product 4-hydroxynonenal. J. Neurochem. 69: 273-284.

38. Blanc, E.M., J.N. Keller, S. Fernandez \& M.P. Mattson. 1998. 4-hydroxynonenal, a lipid peroxidation product, inhibits glutamate transport in astrocytes. Glia 22: $149-160$.

39. Goodman, Y., A.J. Bruce, B. Cheng \& M.P. Mattson. 1996. Estrogens attenuate and corticosterone exacerbates excitotoxicity, oxidative injury and amyloid $\beta$-peptide toxicity in hippocampal neurons. J. Neurochem. 66: 1836-1844.

40. Keller, J.N. \& M.P. MatTSON. 1997. 17ß-estradiol attenuates oxidative impairment of synaptic $\mathrm{Na}^{+} / \mathrm{K}^{+}$-ATPase activity, glucose transport and glutamate transport induced by amyloid $\beta$-peptide and iron. J. Neurosci. Res. 50: 522-530.

41. Blanc, E.M., M. Toborek, R.J. Mark, B. Hennig \& M.P. Mattson. 1997. Amyloid $\beta$-peptide disrupts barrier and transport functions and induces apoptosis in vascular endothelial cells. J. Neurochem. 68: 1870-1881.

42. Keller, J.N., M.S. Kindy, F.W. Holtsberg, D.K. St Clair, H.-C. Yen, A. Germeyer, S.M. Steiner, A.J. Bruce-Keller, J.B. Hutchins \& M.P. Mattson. 1998. Mitochondrial MnSOD prevents neural apoptosis and reduces ischemic brain injury: suppression of peroxynitrite production, lipid peroxidation and mitochondrial dysfunction. J. Neurosci. 18: 687-697.

43. Kruman, I., Z. Pang, J.W. Geddes \& M.P. Mattson. 1999. Pivotal role of mitochondrial calcium uptake in neural cell apoptosis and necrosis. J. Neurochem. 72: 529-540.

44. Bozner, P., V. Grishko, S.P. LeDoux, G.L. Wilson, Y.C. Chyan \& M.A. PaPPOLLA. 1997. The amyloid beta protein induces oxidative damage of mitochondrial DNA. J. Neuropathol. Exp. Neurol. 56: 1356-1362.

45. Furukawa, K., B. Sopher, R.E. Rydel, J.G. Begley, G.M. Martin \& M.P. MattSON. 1996. Increased activity-regulating and neuroprotective efficacy of $\alpha$-secretase-derived secreted APP is conferred by a C-terminal heparin-binding domain. J. Neurochem. 67: 1882-1896.

46. Lannfelt, L., H. Basun, L.O. Wahlund, B.A. Rowe \& S.L. Wagner. 1995. Decreased $\alpha$-secretase-cleaved amyloid precursor protein as a diagnostic marker for Alzheimer's disease. Nature Med. 1: 829-832.

47. Mattson, M.P., B. Cheng, A. Culwell, F. Esch, I. Lieberburg \& R.E. Rydel. 1993. Evidence for excitoprotective and intraneuronal calcium-regulating roles for secreted forms of $\beta$-amyloid precursor protein. Neuron 10: 243-254.

48. Smith-Swintosky, V.L., L.C. Pettigrew, S.D. Craddock, A.R. Culwell, R.E. RYDEL \& M.P. MATTSON. 1994. Secreted forms of $\beta$-amyloid precursor protein protect against ischemic brain injury. J. Neurochem. 63: 781-784.

49. Furukawa, K., S.W. Barger, E. Blalock \& M.P. Mattson. 1996. Activation of K ${ }^{+}$ channels and suppression of neuronal activity by secreted $\beta$-amyloid precursor protein. Nature 379: $74-78$. 
50. BARGER, S.W. \& M.P. MATtSON. 1996. Induction of neuroprotective $\kappa B$-dependent transcription by secreted forms of the Alzheimer's $\beta$-amyloid precursor. Mol. Brain Res. 40: 116-126.

51. Barger, S.W., D. Horster, K. Furukawa, Y. Goodman, J. Krieglstein \& M.P. Mattson. 1995. Tumor necrosis factors $\alpha$ and $\beta$ protect neurons against amyloid $\beta$-peptide toxicity: evidence for involvement of a $\mathrm{\kappa B}$-binding factor and attenuation of peroxide and $\mathrm{Ca}^{2+}$ accumulation. Proc. Natl. Acad. Sci. USA 92: 93289332.

52. Mattson, M.P., Y. Goodman, H. Luo, W. Fu \& K. Furukawa. 1997. Activation of NF- $\kappa B$ protects hippocampal neurons against oxidative stress-induced apoptosis: evidence for induction of Mn-SOD and suppression of peroxynitrite production and protein tyrosine nitration. J. Neurosci. Res. 49: 681-697.

53. Mattson, M. P., Z. H. Guo \& J. D. Geiger. 1999. Secreted form of amyloid precursor protein attenuates oxidative impairment of glucose and glutamate transport in synaptosomes by a cyclic GMP-mediated mechanism. J. Neurochem. 73: 532-537.

54. Guo, Q., B.L. Sopher, D.G. Pham, K. Furukawa, N. Robinson, G.M. Martin \& M.P. MatTson. 1997. Alzheimer's presenilin mutation sensitizes neural cells to apoptosis induced by trophic factor withdrawal and amyloid $\beta$-peptide: involvement of calcium and oxyradicals. J. Neurosci. 17: 4212-4222.

55. Guo, Q., S. Christakos, N. Robinson \& M.P. Mattson. 1998. Calbindin blocks the pro-apoptotic actions of mutant presenilin-1: reduced oxidative stress and preserved mitochondrial function. Proc. Natl. Acad. Sci. USA 95: 3227-3232.

56. Guo, Q., W. Fu, B.L. Sopher, M.W. Miller, C.B Ware, G.M. Martin \& M.P. MATTSON. 1999. Increased vulnerability of hippocampal neurons to excitotoxic necrosis in presenilin-1 mutant knockin mice. Nature Med. 5: 101-107.

57. Begley, J.G., W. Duan, K. Duff \& M.P. Mattson. 1999. Altered calcium homeostasis and mitochondrial dysfunction in cortical synaptic compartments of presenilin-1 mutant mice. J. Neurochem. 72: 1030-1039.

58. Guo, Q., K. Furukawa, B.L. Sopher, D.G. Pham, N. Robinson, G.M. Martin \& M.P. MATTSON. 1996. Alzheimer's PS-1 mutation perturbs calcium homeostasis and sensitizes PC12 cells to death induced by amyloid $\beta$-peptide. NeuroReport 8: 379-383.

59. Mattson, M.P., N. Robinson \& Q. Guo. 1997. Estrogens stabilize mitochondrial function and protect neural cells against the pro-apoptotic action of mutant presenilin-1. NeuroReport 8: 3817-3821.

60. Guo, Q., W. Fu, B.L. Sopher, F.W. Holtsberg, S.M. Steiner \& M.P. Mattson. 1999. Superoxide mediates the apoptosis-enhancing action of presenilin-1 mutations. J. Neurosci. Res. 56: 457-470.

61. Duan, W., D.M. Gash, V. Rangnekar \& M.P. Mattson. 1999. Participation of Par4 in degeneration of dopaminergic neurons in primate and rodent models of Parkinson's disease. Ann. Neurol. 46: 587-597.

62. Tipton, K.F. \& T.P. Singer. 1993. Advances in our understanding of the mechanisms of the neurotoxicity of MPTP and related compounds. J. Neurochem. 61: $1191-1206$.

63. El-Agnaf, O.M., R. Jakes, M.D. Curran, D. Middleton, R. Ingenito, E. Bianchi, A. Pessi, D. Neill \& A. Wallace. 1998. Aggregates from mutant and wild-type alpha-synuclein proteins and NAC peptide induce apoptotic cell death in human neuroblastoma cells by formation of beta-sheet and amyloid-like filaments. FEBS Lett. 440: 71-75.

64. Mattson, M.P. 1998. Modification of ion homeostasis by lipid peroxidation: roles in neuronal degeneration and adaptive plasticity. Trends Neurosci. 21: 53-57. 
65. Anglade, P., A. Mouatt-Prigent, Y. Agid \& E. Hirsch. 1996. Synaptic plasticity in the caudate nucleus of patients with Parkinson's disease. Neurodegeneration 5: $121-128$.

66. Mitchell, I.J. \& C. B. CARroll. 1997. Reversal of parkinsonian symptoms in primates by antagonism of excitatory amino acid transmission: potential mechanisms of action. Neurosci. Biobehav. Rev. 21: 469-475.

67. Mattson, M.P., J.N. KelleR \& J.G. Begley. 1998. Evidence for synaptic apoptosis. Exp. Neurol. 153: 35-48.

68. Mattson, M.P., J. Partin \& J.G. Begley. 1998. Amyloid $\beta$-peptide induces apoptosis-related events in synapses and dendrites. Brain Res. 807: 167-176.

69. Duan, W., V. Rangnekar \& M.P. Mattson. 1999. Par-4 production in synaptic compartments following apoptotic and excitotoxic insults: evidence for a pivotal role in mitochondrial dysfunction and neuronal degeneration. J. Neurochem. 72: 2312-2322.

70. Sells, S.F., S.-S. Han, S. Muthukkumar, N. Maddiwar, R. Johnstone, E. Boghaert, D. Gillis, G. Liu, P. Nair, S. Monnig, P. Collini, M.P. Mattson, V. P. Sukhatme, S.G. Zimmer, D.P. Wood, J.W. McRoberts, Y. Shi \& V.M. RangNEKAR. 1997. Expression and function of the leucine zipper protein Par-4 in apoptosis. Mol. Cell. Biol. 17: 3823-3832.

71. Guo, Q., W. Fu, J. Xie, H. Luo, S.F. Sells, J.W. Geddes, V. Bondada, V.M. RanGNEKAR \& M.P. MATTSON. 1998. Par-4 is a mediator of neuronal degeneration associated with the pathogenesis of Alzheimer's disease. Nature Med. 4: 957-962.

72. Diaz-Meco, M.T., M.M. Municio, S. Frutos, P. Sanchez, J. Lozano, L. Sanz \& J. Moscat. 1996. The product of par-4, a gene induced during apoptosis, interacts selectively with the atypical isoforms of protein kinase C. Cell 86: 777-786.

73. Gnanalingham, K.K., N.A. Milkowski, L.A. Smith, A.J. Hunter, P. Jenner \& C.D. MARSDEN. 1995. Short and long-term changes in cerebral $\left[{ }^{14} \mathrm{C}\right]-2$-deoxyglucose uptake in the MPTP-treated marmoset: relationship to locomotor activity. J. Neural. Transm. Gen. Sect. 101: 65-82.

74. Sorbi, S., S. Piacentini, S. Latorraca, P. Piersanti \& L. Amaducci. 1995. Alterations in metabolic properties in fibroblasts in Alzheimer disease. Alzheimer Dis. Assoc. Disord. 9: 73-77.

75. Messier, C. \& M. Gagnon. 1996. Glucose regulation and cognitive functions: relation to Alzheimer's disease and diabetes. Behav. Brain Res. 75: 1-11.

76. Vanhanen, M. \& H. Solninen. 1998. Glucose intolerance, cognitive impairment and Alzheimer's disease. Curr. Opin. Neurol. 11: 673-677.

77. Molchan, S.E., J.L. Hill, A.M. Mellow, B.A. Lawlor, R. Martinez \& T. SunDERLAND. 1990. The dexamethasone suppression test in Alzheimer's disease and major depression: relationship to dementia severity, depression, and CSF monoamines. Int. Psychogeriatr. 2: 99-122.

78. Pedersen, W.A., C. Culmsee, D. Ziegler, J.P. Herman \& M.P. Mattson. 1990. Aberrant stress response associated with severe hypoglycemia in a transgenic mouse model of Alzheimer's disease. J. Mol. Neurosci. 13: 159-165.

79. SANDYK, R. 1993. The relationship between diabetes mellitus and Parkinson's disease. Int. J. Neurosci. 69: 125-130.

80. Shimizu, H., Y. Shimomura, M. Takahashi, I. Kobayashi \& S. Kobayashi. 1990. Dopamine receptor in the streptozotocin-induced diabetic rats. Exp. Clin. Endocrinol. 95: 263-266.

81. Sohal, R.S. \& R. Weindruch. 1996. Oxidative stress, caloric restriction, and aging. Science 273: 59-63.

82. Cefalu, W.T., J.D. Wagner, Z.Q. Wang, A.D. Bell-Farrow, J. Collins, D. HASKell, R. BEChTOLD \& T. MoRgan. 1997. A study of caloric restriction and car- 
diovascular aging in cynomolgus monkeys (Macaca fascicularis): a potential model for aging research. J. Gerontol. A Biol. Sci. Med. Sci. 52: B10-B19.

83. Lane, M.A., D.J. Baer, W.V. Rumpler, R. Weindruch, D.K. Ingram, E.M. TilMONT, R.G. CUTLER \& G.S. Roth. 1996. Calorie restriction lowers body temperature in rhesus monkeys, consistent with a postulated anti-aging mechanism in rodents. Proc. Natl. Acad. Sci. USA 93: 4159-4164.

84. Dubey, A., M.J. Forster, H. Lal \& R.S. Sohal. 1996. Effect of age and caloric intake on protein oxidation in different brain regions and on behavioral functions of mouse. Arch. Biochem. Biophys. 333: 189-197.

85. Aksenova, M.V., M.Y. Aksenov, J.M. Carney \& D.A. Butterfield. 1998. Protein oxidation and enzyme activity decline in old brown Norway rats are reduced by dietary restriction. Mech. Ageing Dev. 100: 157-168.

86. Grant, W. 1997. Dietary links to Alzheimer's disease. Alz. Dis. Rev. 2: 42-55.

87. Bruce-Keller, A.J., G. Umberger, R. McFall \& M.P. Mattson. 1999. Food restriction reduces brain damage and improves behavioral outcome following excitotoxic and metabolic insults. Ann. Neurol. 45: 8-15.

88. Duan, W. \& M.P. Mattson. 1999. Dietary restriction and 2-deoxyglucose administration improve behavioral outcome and reduce degeneration of dopaminergic neurons in models of Parkinson's disease. J. Neurochem. Submitted.

89. Lee, J., A.J. Bruce-Keller, U. Kruman, S.L. Chan \& M.P. Mattson. 1999. 2deoxy-D-glucose protects hippocampal neurons against excitotoxic and oxidative injury: involvement of stress proteins. J. Neurosci. Res. In press.

90. YU, Z.F. \& M.P. MatTson. 1999. Dietary restriction and 2-deoxyglucose administration reduce focal ischemic brain damage and improve behavioral outcome: evidence for a preconditioning mechanism. J. Neurosci. Res. 57: 830-839.

91. Mattson, M.P. 1990. Antigenic changes similar to those seen in neurofibrillary tangles are elicited by glutamate and $\mathrm{Ca}^{2+}$ influx in cultured hippocampal neurons. Neuron 4: 105-117.

92. Cheng, B. \& M.P. Mattson. 1992. Glucose deprivation elicits neurofibrillary tangle-like antigenic changes in hippocampal neurons: prevention by NGF and bFGF. Exp. Neurol. 117: 114-123.

93. Busciglio, J., A. Lorenzo, J. Yeh \& B.A. Yankner. 1995. $\beta$-amyloid fibrils induce tau phosphorylation and loss of microtubule binding. Neuron 14: 879-888.

94. Elliott, E., M.P. Mattson, P. Vanderklish, G. Lynch, I. Chang \& R.M. SapolSKY. 1993. Corticosterone exacerbates kainate-induced alterations in hippocampal tau immunoreactivity and spectrin proteolysis in vivo. J. Neurochem. 61: 57-67.

95. Stein-Behrens, B., M.P. Mattson, I. Chang, M. Yeh \& R.M. Sapolsky. 1994. Stress excacerbates neuron loss and cytoskeletal pathology in the hippocampus. J. Neurosci. 1: 5373-5380.

96. Hsiao, K., P. Chapman, S. Nilsen, C. Eckman, Y. Harigaya, S. Younkin, F. Yang $\&$ G. Cole. 1996. Correlative memory deficits, $A \beta$ elevation, and amyloid plaques in transgenic mice. Science 274: 99-102. 